\title{
The education strategy of student advisor on college students
}

\author{
Ying Song, Jing SUN \\ Harbin University of Science and Technology Rongcheng Campus, Rongcheng 264300, China. \\ 358339383@qq.com, 19761092@qq.com.
}

Key words: Student advisor, method, education strategy.

\begin{abstract}
College students have significant characteristics in the physical, psychological and ideological understanding. Their plasticity are extremely strong. In the process of education, student advisor must take the corresponding education strategy. This paper introduces the roughly working content of counselors and methods for students' education.
\end{abstract}

\section{Introduction}

College students are generally young people around the age of twenty. In terms of physically, their body development is rapid, their body grows rapidly and the development of the brain and nervous system is fast. In psychologically, their intelligence development is rapid, their memory, observation, understanding, imagination are significantly high, and their emotional and interest is extensive, self-awareness and independent consciousness is stronger. In thought, they are in the period of known and unknown, positive factors and negative factors exist in the same time and with low discrimination. So their plasticity is extremely strong and it is the key period for education. The education of college students must be based on the characteristics of their mind and thoughts to adopt corresponding education strategy.

\section{Freshmen education}

Freshman at the beginning of entering the university must be faced with a difficult psychological adaptation. For lack of psychological preparation of college freshmen may produce different degrees of adjustment problems in the process of the psychological transformation and reshaping. This requires college counselors to assume for college freshmen enrolled education work and pay attention to the psychological adjustment to help them through the psychological imbalance

\subsection{Enlightenment class education}

Let students learn the history and the new situation of the school and make them proud of school. They can take the following measures: (1) Holding a grand entrance ceremony; school leaders speech; representatives of old speech; speech agenda can promote the new understanding of the school; (2) Inviting school leader to introduce the new project, to increase deepen understanding further strength of the new understanding and passion; (3) Organizing students to visit the history museum and the main campus facilities, so that the students intuitive feel the history change of school, familiar with the campus environment. (4) Introducing new organizations related to the student's name, basic functions, offices, office phone and its geographical position, to understand new difficulties that need to seek help and advice to find the specific department, in order to increase the ability of self-management ${ }^{[1]}$.

\subsection{Cultivating cadre}

Student cadres is the counselor to do a good job of student's strong support and important force in 
the freshmen entrance education instructors to do early seedling, and culture. In the senior students of party members, cadres out a batch of excellent member for assistant counselors take part in the new work and new students education activities, strengthen the communication of old and new student cadre, mainly by the teachers management gradually transition to the students' self-management is given priority to, instructors will focus on the guidance, planning, supervision and inspection, to strengthen the students' master consciousness, improve the students' ability of organization and management ${ }^{[2]}$.

\section{Tutors play an important part in students' military training}

Military training is a systematic large-scale project, needs the school leaders at all levels attach great importance to, forces and schools need to work together and write each other among different functional departments. Departments need to have a large number of right-hand man to grasp implementation. "The counselor is the backbone to carry out the ideological and political education are for the management of daily ideological and political education of university students and the organizers, practitioners and mentors. Counselors should strive to become a student of life mentors and healthy growth of bosom friends," ${ }^{[3]}$. As the important carrier of higher education, the military training is a counselor to carry out the important position of ideological and political education work. Facts have proven that in the process of military training in colleges. The counselor from beginning to end plays a very important and irreplaceable role. Counselor of your work throughout the course of military skills training, involving military training logistics, team establishment, personnel management, and other aspects. In fact, the counselor is the new contact most teacher during military training. As a result, the counselor work directly affects the quality of the freshman military training. Military training affects the expected effect. Moreover, the counselor's role play level which is closely related to college students' military training are inseparable.

When freshmen appear negative thought emotion, counselors are bosom friends. Currently the vast majority of the freshmen in colleges and universities is an only child who grow up without experienced setbacks. After entering university, 14 days to finish in hard environment of high strength and military skills training. This is not an easy thing. Therefore, the new thought training in the mountain of difficulties and other negative emotions are also inevitable.

When the freshmen face some problems in the life, the tutors are friendly assistant. Although many freshmen have a high school in the school accommodation, but the distance is far beyond the study and independent life. This is the first time for most of the freshmen. In an unfamiliar environment, meet with difficulties in life is inevitable. And adaptation is not fully start military training in the past, coupled with military training has its particularity, this phase is often encounter new problems in life most.

In the new "plateau", student advisors are special instructors on the training. Military training for students is a test challenge of endurance and perseverance. After a period of hard training, the new students have produced a state of exhaustion. This is not only the physical but also the psychological.

In the new understanding of situation and policy is not in place. Military training to guide the freshmen from school start consciously recognize the complicated international situation, face the opportunities and challenges facing our country, identification of communism beliefs, enhance national self-confidence and sense of social responsibility, encouraging them to active service to grasp the future, to become a useful person.

When new psychological problems, the counselor is caring consultant. Military training will also encounter such as family economic difficulties students economic pressure and the special student's 
psychological problems such as counselors to psychological consultant role at this moment and listen to the student voice. College students into the new learning environment will inevitably produce some psychological that don't adapt to it $^{[4]}$. Healthy psychological quality is an important part of quality education and also the foundation of personal achievement and carrier.

\section{How to do a good job of college freshman class construction}

Freshman class which is the beginning point of college freshmen university life is very critical and important. For the students, the class is not only a school the education and management activities of the organizations at the grass-roots level, but also the college students' self-education, self-management of grassroots community, especially counselors rely on class management and education.

\subsection{To do a good job of class management, build good class phenomenon, the style of study}

It is important to do a good job of freshman class committee selection. The good class cadre voting can based on passing examination, observation and forms of democratic elections, screening, trial, and so on. The students with both ability and political integrity, to participate in class's and grade's management will be used. In view of the new features, at the beginning of the school would most desire is more intense, so more carefully in class committee's selection process. We should take the process more carefully Encourage students to carry out the activities of rich and colorful style. After the freshman class basically stable, in order to further advance the class construction, make students from all over the world can really start to fusion, causes the student to have a sense of belonging. It is necessary in the class and grade in the form of colorful, rich variety of campus cultural activities, as the carrier, to strengthen the students' collective sense of honor, improve the quality of the individual and population quality, promote the formation of good style of study, class phenomenon plays an important role. On one hand, according to the students' opinion within a class of spontaneous organizations are beneficial to the ideas of activities; On the other hand, more competitive activities should be hold with a fair between classes, such as debate, singing, ball games, and so on. Students in the activity not only cheerful the mood, virtually also enhanced the collective consciousness, enhance the collective cohesion and combat effectiveness.

\subsection{Trying to play the role of counselor in class construction}

The student advisors should be a good guider of class construction. As for the functions in the actual work of the construction of the class, the first thing is to be a good guider, trust respect each student, let them in class in the actual work of independent thinking, independent analysis and solve the problem, this can also increase the pertinence of the construction of the class. At the same time to deal with the relationship between instructors and class leader. Making contact everybody recognized the class cadre is the bridge and the link to the relationship between teachers and students, communication between teachers and students' emotion. Mentor is equality between teachers and students love and relationship. Counselor's main duty is to determine the class of the construction of the guiding ideology, to establish a practical and feasible management and education mechanism, grasp the correct direction for the construction of class, solve some important problems in the course of the construction of class, checking the deployment plan and working summary work.

Seize the characteristic of new students, innovate the communication style between teachers and students form along with the network popularization. The network interpersonal communication is a new type of interpersonal interaction in cyberspace. It is very popular with the college students. Now, college students are close to the generation after 90. They prefer this kind of form in the exchanges, especially QQ and faction this kind of network communication. In the author of the new, 
I built the QQ group convenient for exchange and communication between students and, deep love of students. In ordinary, they speak out a lot of words they do not willing to say. At the same time, between various classes have built the class QQ group to open communication and communication between the classmates.

\section{The education strategy of student advisor on college students'}

\subsection{Fully rely on student cadres for students' self-education and self-management}

The student advisor should give up the idea of "education is a kind of control". In practical work, have a number of participants enthusiastically, hands-on, lest to go wrong, with a lot of discipline to restrain students, ever-present ACTS as a "housekeeper" or "nanny" role. They control too much, not conducive to the free development of college students' personality and the all-round development of body and mind. And also student advisor would fall into the formation of college students' self-education and self-management ability influence, easy to make college students management affairs of counselors in complicated busy situation without a sense of achievement, in the long term the counselor will generate job burnout.

\subsection{To keep a proper distance between teachers and students to}

Counselors and the relationship between college students should be "democracy, equality and harmony". Counselors should take the equal Angle of view, love feelings to each college student, it is easy to enter the in the mind of college students, and students' emotional resonance, in this way, the counselor's job is the psychological basis of solid and reliable. Education in essence is a kind of state, the process of education essence is the process of "psychological exchange" educators and those being educated, only the emotion education, will cause the students emotional resonance. In daily college students' education work, counselors must stand in the Angle of the college students to think more problems, actively explore and point where college students emotional mind, make students truly regard the counselor as their bosom friends, willing to open their hearts to the counselor. Only at this point, the counselor can rich make great achievements effect on college students' management work.

\section{References}

[1] Xiaoping Qi, Yan Tang, College Student Affairs Management, Guang Zhou: Zhongshan University Press, 2004.

[2] Li Zhang, Discussion on the entrance education of Freshmen, Journal of Beijing City University, 2007 (6): 35-47.

[3] The Ministry of education No.24 Provisions on the construction of College Counselors Team, 2006-09-01.

[4] Yang Chen, QiHua Tang, Countermeasures and discussion of college entrance education for College Students, Journal of Southwest Agricultural University: Social Science Edition, 2008(4):153-155. 